\title{
Effect of fluoride on salivary immunoglobulins and sialic acid
}

\author{
Kadriye Görkem Ulu Güzel ${ }^{1 *}$, Zuhal KirzıoĞlu² ${ }^{2}$ Ali Kudret Adiloğlu³ ${ }^{3}$, Münciye Semra Özay Ertürk ${ }^{4}$ \\ ${ }^{1} \mathrm{PhD}$, Assistant Professor, Department of Pediatric Dentistry, Faculty of Dentistry, Adnan Menderes University, Aydın, Turkey \\ ${ }^{2} \mathrm{PhD}$, Professor, Department of Pediatric Dentistry, Faculty of Dentistry, Süleyman Demirel University, Isparta, Turkey \\ ${ }^{3} \mathrm{MD}$. Clinical Microbiology Specialist Professor, Department of Microbiology, Faculty of Medicine, Bülent Ecevit University, Zonguldak, Turkey \\ ${ }^{4} \mathrm{PhD}$, Pediatric Dentist, Private Clinic, Antalya, Turkey
}

Study conducted at Süleyman Demirel University, Scientific Research Project Coordination Unit, Isparta, Turkey

Article received: $1 / 17 / 2016$ Accepted for publication: 1/23/2016

*Correspondence: Hasan Efendi Mah. Adnan Menderes Üniversitesi Diş Hekimliği Fakültesi Pedodonti AD. 09100

gorkemulu@yahoo.com

\section{SUMMARY}

Objective: The aim of our study was to evaluate the effect of fluoride on salivary immunoglobulin and sialic acid levels in children with dental fluorosis and healthy teeth who live in places with high fluoride concentration in drinking water.

Method: Fifty-one (51) healthy children between 6 and 12 years old with no caries were randomly selected from primary schools enrolled in the dental-care program operated by the Department of Pediatric Dentistry. The children were divided into two groups: group I comprised 26 children with dental fluorosis [Thylstrup-Fejerskov Dental Fluorosis Index $(\mathrm{TFI})=4$ ] who lived in Isparta (2.7-2.8 ppm), and group II consisted of 25 children without dental fluorosis who were born in low-fluoride areas and had lived in Isparta for only the previous two years. Stimulated and unstimulated saliva were collected and analyzed for fluoride, salivary immunoglobulins and sialic acid levels.

Results: Sialic acid level was correlated negatively with age. Levels of secretory immunoglobulin A (sIgA) and secretory immunoglobulin G (sIgG) were higher in children with dental fluorosis compared with those in group II, although these differences were not significant.

Conclusion: Increased sIgA and sIgG levels may arrest the progression of caries in subjects with dental fluorosis. Given the risks of dental fluorosis, further studies of the effects of different fluoride levels in drinking water on salivary composition of children with mixed dentition are needed to confirm the results of our study and to provide data for comparison.

Keywords: dental fluorosis, fluoride, sialic acid, salivary immunoglobulin.

\section{INTRODUCTION}

Salivary secretions are important for the maintenance of oral health. In the human saliva, there are components that control the composition of oral microflora and the function of microorganisms. The main proteins, peptides and enzymes in human saliva have been identified and characterized. ${ }^{1-4}$ Macromolecules in the saliva have different functions and biochemical properties.

The protective role of saliva includes a buffer effect, flow rate, immune and non-immune antimicrobial factors and minerals that support enamel tissue, such as calcium, phosphorus and fluoride. ${ }^{4}$ Salivary flow rate, $\mathrm{pH}$, buffering capacity, calcium-phosphate homeostasis and effects on bacterial metabolism are important findings of the saliva-caries interaction. ${ }^{5}$
Sialic acid is an important structural component of salivary glycoproteins, having an essential role in enhancing bacterial agglutination. Sialic acid-containing glycoproteins are also important structural components of the acquired pellicle and of dental plaque. ${ }^{6}$

Salivary secretory immunoglobulin A (sIgA) antibodies play an important role in the immune response against dental caries, which are generated by mucosa-associated lymphoid tissue (MALT) common in the mucosal immune system. These antibodies may reduce the initial adhering of bacteria to saliva-coated teeth surfaces and neutralize extracellular enzymes. ${ }^{7}$ It has been reported that caries-free patients have significantly higher levels of naturally occurring salivary sIgA compared with caries-active subjects. ${ }^{8}$ Results of previous studies have led researchers to believe 
that there is a negative correlation between salivary $\operatorname{sig} \mathrm{A}$ and dental caries. ${ }^{9,10}$ Several studies have reported that caries were particularly correlated with sIgA and sIgG. ${ }^{11-13}$ In addition, many studies demonstrated that high salivary sIgA levels result in lower incidence of dental caries. ${ }^{14-16}$

With the increasing use of fluoride products, dental fluorosis has become more common. Dental fluorosis is characterized by enamel hypomineralisation with increased surface and subsurface porosity, which causes opacity, pitting, or staining of the enamel. Information about changes in $\operatorname{sg} A, \operatorname{sgG}$, and sialic acid levels in the presence of dental fluorosis is limited.

The aim of our study was to evaluate the effects of fluoride on salivary $\operatorname{sgA}, \operatorname{sg} G$, and sialic acid levels in children with dental fluorosis and those with healthy teeth. In addition, the effects of high levels of fluoride in drinking water on the salivary content were evaluated.

\section{Method}

The ethical committee of Süleyman Demirel University's Faculty of Medicine approved the study. All participants and their parents/guardian were informed about the study and a written consent was obtained for all children.

Isparta Province, Turkey, is a region of endemic fluorosis with high fluoride levels $(2.7-2.8 \mathrm{ppm})$ in drinking water. Children in six primary schools were chosen to participate. Children and their parents filled out a total of 1,026 questionnaires with items regarding the duration of residence in Isparta, place of birth, tooth-brushing and daily dietary habits, systemic diseases, and socio-economic status. Children were examined for oral hygiene, dental plaque index and caries status. The forms were reviewed and 473 children were identified with similar features. Children were examined and oral hygiene instructions were given again at our clinic. Before starting the collection of saliva, the criteria for inclusion were that: (a) the patients should be healthy and free of systemic disease; (b) the patients should not have consumed any medications for at least 15 days before saliva collection; (c) the patients' first permanent molars should have erupted fully; (d) there should be equal portions of male and females participants; (e) and they should have the same fluorosis index.

According to these criteria, 51 healthy 6 to 12 year-old $(9,15 \pm 1,17)$ children were randomly selected from the primary schools enrolled in a dental-care program maintained by the Department of Pediatric Dentistry. The children were divided into two groups: group I comprised 26 children with dental fluorosis [Thylstrup-Fejerskov Dental Fluorosis Index $(\mathrm{TFI})=4]^{17}$ who lived in Isparta (2.7-2.8 ppm), and group II consisted of 25 children with- out dental fluorosis who were born in low-fluoride areas and had lived in Isparta for only the previous two years. The groups are summarized in Figure 1.

\section{Saliva sample collection}

A special diet was assigned to the participants for breakfast and the teachers were instructed not to give any food/ beverage except water to the children after breakfast on the day of saliva collection. The saliva was collected in the morning (10-10:30 am) to minimize circadian rhythm effects. The samples were collected in a quiet, isolated, ventilated and lighted room, at room temperature.

After an initial swallow of saliva, the unstimulated saliva was collected into sterilized polyethylene cups. For saliva stimulation, participants were asked to chew on one piece $(1 \mathrm{~g})$ of unsweetened, unflavored chewing gum for 2 minutes. The saliva produced in the first 30 seconds was expectorated. The subjects spat $4 \mathrm{~mL}$ of saliva into the second sterilized cup. The unstimulated saliva was used for saliva immunoglobulin analyses and the stimulated saliva was used for salivary fluoride and sialic acid analyses.

\section{Analysis of the saliva samples}

The salivary immunoglobulin levels were evaluated using ELISA method. The salivary sialic acid levels were determined using Sigma Sialic Acid Quantitation Kit (Sigma-Aldrich Inc., Missouri, USA). The salivary levels of fluoride were analyzed by fluoride electrode.

\section{Statistical analysis}

Results were analyzed statistically by Mann-Whitney-U test and Kruskall-Wallis. All analyses were performed using the SPSS statistical package for Windows version 13.0 (SPSS, Chicago, IL, USA). All levels of significance were set at $\mathrm{p}<0.05$.

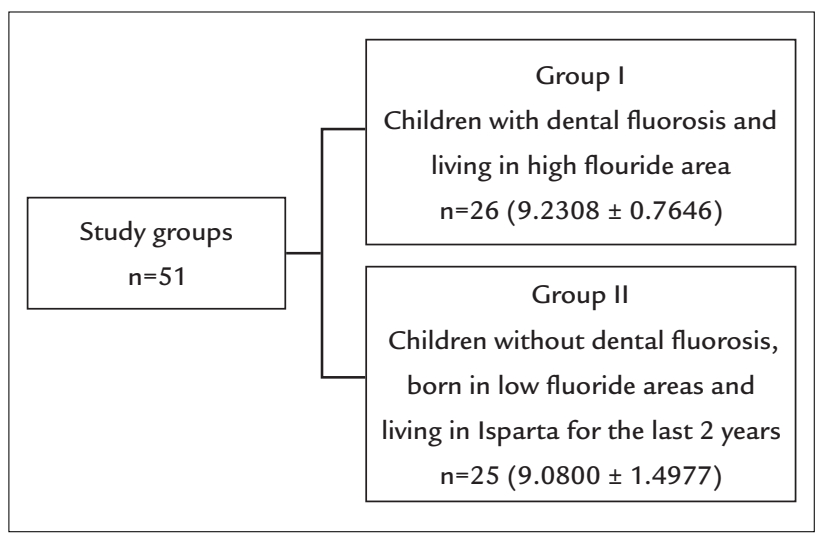

FIGURE 1 The study and control groups. 


\section{RESULTS}

Table 1 and Table 2 show the results for salivary fluoride, sIgA, sIgG and sialic acid levels in the children of both groups.

No statistically significant difference was found in salivary fluoride levels between group I and II. A significant negative correlation was found between salivary fluoride level and age $(\mathrm{p}<0.005,0.025)$ in all subjects. No relationship was observed between dental fluorosis and salivary fluoride, sIgA, sIgG, or sialic acid level.

The sialic acid level differed significantly according to age; this level was much lower in older children.

The SIgA and sIgG concentrations were similar. A negative correlation was found between $\operatorname{SIgA}$ and sialic acid levels ( $p<0.05,0.028)$. Salivary sIgA levels were higher and sialic acid levels were lower in group I compared to group II, but these differences were not significant.

\section{Discussion}

There are various factors affecting secretion and composition of saliva, such as age, sex, number of teeth, weight, stress, diseases or medications causing hypo salivation/ hyper salivation, environmental factors and radiation. ${ }^{18}$ According to these factors, 51 children aged 6-12 years with mixed dentition and fully erupted permanent first molars were included in our study. Despite the standardization of study factors, the groups were not equivalent in terms of the number or age of included children.

In our study, TFI, which is based on visual examination, was used to determine the severity of dental fluorosis. Children with TFI scores of 4 were included in the study. TFI scores of 5 are well-known to progress rapidly to 6 , with the rate of progression increasing after the loss of surface enamel.

Despite the attention given to the collection of unstimulated saliva in our study, the movement of children's tongues and cheeks during expectoration may have caused mechanical stimulation, which would change the salivary composition.
In the study, we compared the levels of salivary fluoride of the children with dental fluorosis or healthy teeth and there was no statistically significant differences recorded. However, salivary fluoride levels decreased with increasing age in both groups. Difficulties allocating the children into groups that met all the study parameters also occurred, namely: an equal number of children in both groups with the same number of teeth could not be controlled, in addition to individual variety and effects of soft tissues and reservoir systems in the mouth, such as plaque and teeth, which affect the secretion and retention of fluoride and have different properties at different ages.

Martin-Gomez et al. ${ }^{19}$ reported that the salivary sialic acid concentration in children with TFIs $\geq 2$ was lower than that of controls. In our study, the sialic acid concentration was higher in group II compared with group I, whereas sIgA and sIgG levels were higher in the dental fluorosis group; however, these differences were not significant.

The relation between SIgA, sIgG and sialic acid levels has been investigated in geriatrics patients. It is reported that a negative correlation was found between total IgA and sialic acid. ${ }^{6}$

In our study, the level of SIgA was related to sialic acid and increasing of SIgA was associated with decreasing of sialic acid in mixed dentition. Our results suggest that the dental plaque is negatively affected with decreased sIgA and sialic acid levels. However, comparison of our findings from children with mixed dentition with those of other studies is difficult, given the lack of available studies conducted in different age groups.

In two different studies, breastfed infants, compared with formula-fed infants, were found to have almost two times more sialic acid in the saliva. ${ }^{20,21}$ Salivary sialic acid was measured in children separated in three age groups: 18,30 and 42 months. Sialic acid concentrations were higher in the first group than in the third group. ${ }^{22} \mathrm{Al}-$ though our study was performed in children but not babies, the results showed similarities with those obtained

TABLE 1 Comparison of means according to group.

\begin{tabular}{lllll} 
Salivary parameters & Fluoride $(\mathbf{p p m})$ & $\mathbf{I g A}(\boldsymbol{\mu g} / \mathbf{m L})$ & IgG $(\mathbf{m g} / \mathbf{d L})$ & Sialic acid $(\boldsymbol{\mu m o l} / \mathbf{m g}$ protein) \\
\hline Group I & $0.0563 \pm 0.0194$ & $445.8462 \pm 175.4654$ & $1.4595 \pm 1.5952$ & $0.0214 \pm 0.0089$ \\
\hline Group II & $0.0543 \pm 0.0168$ & $443.2727 \pm 239.9123$ & $1.0060 \pm 0.6904$ & $0.0223 \pm 0.0076$ \\
\hline
\end{tabular}

TABLE 2 Comparison of means by sex.

\begin{tabular}{lllll} 
Salivary parameters & Fluoride $(\mathbf{p p m})$ & $\operatorname{lgA}(\boldsymbol{\mu g} / \mathbf{m L})$ & IgG $(\mathbf{m g} / \mathbf{d L})$ & Sialic acid $(\boldsymbol{\mu m o l} / \mathbf{m g} \mathbf{p r o t e i n})$ \\
\hline Girl & $0.0538 \pm 0.1636$ & $489.8261 \pm 247.8151$ & $1.8548 \pm 1.7725$ & $0.0250 \pm 0.0053$ \\
\hline Boy & $0.0568 \pm 1974$ & $403.1200 \pm 149.6340$ & $0.8205 \pm 0.3734$ & $0.0189 \pm 0.0098$ \\
\hline
\end{tabular}


from babies including level of sialic acid, which was reduced as the children aged.

Salivary sialic acid levels were compared with those of children with systemic problems. Two studies found that salivary sialic acid levels were higher in healthy individuals than in children with Down syndrome. ${ }^{8,23}$ However, this difference was significant in only one of the two studies. Similarly, the salivary sialic acid level was found to be higher in a control group than in diabetic children. ${ }^{24}$ Patients with cystic fibrosis have been shown to have significantly lower sialic acid concentrations compared with a control group. ${ }^{25}$ These differences in sialic acid level have been interpreted as influenced more by the effects of systemic diseases than by local factors. ${ }^{8}$

\section{Conclusion}

In our study, gathering a large group of children using the same parameters to standardize was quite difficult. We conclude that SIgA and SIgG levels were higher in children with dental fluorosis than in those with healthy teeth, even though the difference was not significant. Therefore, increased levels of sIgA and IgG in dental fluorosis may arrest the progression of dental caries. Given the risks of dental fluorosis, further studies of the effects of different fluoride levels in drinking water on salivary characteristics are needed to confirm the results of our study and to provide data for comparison. Studies conducted in samples with features similar to those of our study will increase the knowledge available.

\section{References}

1. Nieuw Amerongen AV, Veerman ECI. Saliva-the defender of the oral cavity. Oral Dis. 2002; 8(1):12-22.

2. Sreebny LM. Saliva in health and disease: an appraisal and update. Int Dent J. 2000; 50(3):140-61.

3. Mandel ID. The role of saliva in maintaining oral homeostasis. J Am Dent Assoc. 1989; 119(2):298-304.

4. Dodds MWJ, Johnson DA, Yeh CK. Health benefits of saliva: a review. J Dent. 2005; 33(3):223-33.

5. Llena-Puy $\mathrm{C}$. The role of saliva in maintaining oral health and as an aid to diagnosis. Med Oral Patol Oral Cir Bucal. 2006; 11(5):449-55.

6. Närhi TO, Tenovuo J, Ainamo A, Vilja P. Antimicrobial factors, sialic acid, and protein concentration in whole saliva of the elderly. Scand J Dent Res. 1994; 102(2):120-5.

7. Cogulu D, Sabah E, Kutukculer N, Ozkinay F. Evaluation of the relationship between caries indices and salivary secretory $\operatorname{IgA}$, salivary $\mathrm{pH}$, buffering capacity and flow rate in children with Down's syndrome. Arch Oral Biol. 2006; 51(1):23-8.

8. Yarat A, Akyüz S, Koç L, Erdem H, Emekli N. Salivary sialic acid, protein, salivary flow rate, $\mathrm{pH}$, buffering capacity and caries indices in subjects with Down's syndrome. J Dent. 1999; 27(2):115-8.

9. Winer RA, Feller RP. Composition of parotid and submandibular saliva and serum in Down's syndrome. J Dent Res. 1972; 51(2):449-54.

10. Jara L, Ondarza A, Blanco R, Rivera L. Composition of the parotid saliva in Chilean children with Down's syndrome. Arch Biol Med Exp (Santiago). 1991; 24(1):57-60.

11. Riviere GR, Papagiannoulis L. Antibodies to indigenous and laboratory strains of Streptococcus mutans in saliva from children with dental caries and from caries-free children. Pediatr Dent. 1987; 9(3):216-20.

12. Rose PT, Gregory RL, Gfell LE, Hughes CV. IgA antibodies to Streptococcus mutans in caries-resistant and -susceptible children. Pediatr Dent. 1994; $16: 272-6$

13. Russell MW, Hajishengallis G, Childers NK, Michalek SM. Secretory immunity in defense against cariogenic mutans streptococci. Caries Res. 1999; 33(1):4-15.

14. Katz J, Harmon CC, Buckner GP, Richardson GJ, Russell MW, Michalek SM. Protective salivary immunoglobulin A responses against Streptococcus mutans infection after intranasal immunization with $\mathrm{S}$. mutans antigen I/II coupled to the B subunit of cholera toxin. Infect Immun. 1993; 61(5):1964-71.

15. Fontana M, Gfell LE, Gregory RL. Characterization of preparations enriched for Streptococcus mutans fimbriae: salivary immunoglobulin A antibodies in caries-free and caries-active subjects. Clin Diagn Lab Immunol. 1995; 2(6):719-25.

16. Bratthall D, Serinirach R, Hamberg K, Widerström L. Immunoglobulin A reaction to oral streptococci in saliva of subjects with different combination of caries and levels of mutans streptococci. Oral Microbiol Immunol. $1997 ; 12(4): 212-8$.

17. Thylstrup A, Fejerskov O. Clinical appearance of dental fluorosis in permanent teeth in relation to histological changes. Commun Dent Oral Epidemiol. 1978; 6(6):315-28.

18. Axelsson P. Diagnosis and risk prediction of dental caries. Germany: Quintessence Publishing Co; 2000.

19. Martins-Gomez AM, Nicolau J, de Souza D, Oliveira EA. Study of some parameters in stimulated saliva from adolescents with dental fluorosis. J Oral Sci. 2001; 43(4):225-31.

20. Tram TH, Brand Miller JC, McNeil Y, McVeagh P. Sialic acid content of infant saliva: comparison of breast fed with formula fed infants. Arch Dis Child. 1997; 77(4):315-8.

21. Wang B, Miller JB, Sun Y, Ahmad Z, McVeagh P, Petocz P. A longitudinal study of salivary sialic acid in preterm infants: comparison of human milkfed versus formula-fed infants. J Pediatr. 2001; 138(6):914-6.

22. Dezan CC, Nicolau J, Souza DN, Walter LRF. Flow rate, amylase activity, and protein and sialic acid concentrations of saliva from children aged 18, 30 and 42 months attending a baby clinic. Arch Oral Biol. 2002; 47(6):423-7.

23. Siqueria WL, Nicolau J. Stimulated whole saliva components in children with Down syndrome. Special Care Dentist. 2002; 22(6):226-30.

24. Akyüz S, Yarat A, Erdem H, Koç L, Emekli N, İşbüsker A. Tip I ve Tip II diyabetik hastalarda diş çürügüu, periodontal durum ile bazı tükürük parametreleri ve tükürük, serum, mikrobiyal dental plak sialik asit düzeyleri arasındaki ilişkinin incelenmesi. Türk Diyabet Yıllığı. 1997-1998:1-15.

25. da Silva Modesto KB, de Godói Simões JB, de Souza AF, Damaceno N, Duarte $\mathrm{DA}$, Leite MF, et al. Salivary flow rate and biochemical composition analysis in stimulated whole saliva of children with cystic fibrosis. Arch Oral Biol. $2015 ; 60(11): 1650-4$.

26. Pannunzio E, Amancio OM, Vitalle MS, Souza DN, Mendes FM, Nicolau J. Analysis of the stimulated whole saliva in overweight and obese school children. Rev Assoc Med Bras. 2010; 56(1):32-6. 